\title{
CHARACTERISTICS AND TRENDS OF INDICATORS OF EXPORT, IMPORT, AND ELECTRICITY CONSUMPTION IN LATVIA. WIND POWER CONSUMPTION CHARACTERISTICS AND TRENDS
}

\author{
Veronica Silinevicha' ${ }^{1}$
}

\begin{abstract}
Energy markets with high penetration rates of renewables are more likely to face price fluctuations or volatility, which is in part due to the stochastic nature of renewables. Latvia's electricity market is an excellent example of such a market, as more than $40 \%$ of Latvia's electricity generation comes from hydropower, which challenges the projected spot electricity prices for Latvia's electricity market. The article identifies trends in the natural and value indicators of total exports, imports, total currency turnover and electricity consumption in Latvia with a more detailed study of the characteristics and trends of electricity consumption indicators from renewable resources for the period 2014, 2015-2019. In addition, wind power utilization rates were considered both for the observed period as a whole and on a monthly basis for 2019. In general, the results of the study confirm the feasibility of Latvia's plans to increase both total electricity consumption and its share from renewable sources. At the same time, the coronavirus pandemic has already begun to lead to negative consequences for electricity consumption in EU countries, which have so far affected Latvia to a lesser extent. Nevertheless, these consequences will inevitably lead to an adjustment of Latvia's electricity plans towards an increase in the share of production and consumption of electricity from renewable sources, including wind energy, despite its upward price trend. The author with employment of the tools Excel Trendline obtains trends of indicators, approximating formulae dependencies and the coefficients of determination for the relevant diagrams and charts.
\end{abstract}

Key words: electric power indicators of export, import, total exchange turnover and electricity consumption, electricity from renewable sources, trends.

JEL Classifications: E20, C30, R30

\section{Introduction}

Latvia provides detailed statistics on the natural and price indicators of electricity generation and consumption from various types of power plants (TPP), including hydro and wind power plants (HPP and WPP). The current analysis of these indicators carried out both in companies related to the production and distribution of electricity, for example (Central Statistical Bureau of Latvia 2021; JSC Augstsprieguma tìkls, Latvian electricity market overview 2020; European Network of Transmission System Operators for Electricity 2020; Review of RES perspective in Baltic countries till 2030), and in academic environment (Balodis 2020; Prohorova 2020; Viskuba, Silinevicha, 2020; etc.).

Trends, indicators and prospects for the development of Latvia's energy sector in conjunction with climate change for the next decade are reflected in the National Plan of Latvia for 2021-2030.

The author set herself the task of analyzing the dynamics and trends of the indicators under

Corresponding author:

${ }^{1}$ Transport and Telecommunication Institute, Latvia.

E-mail: veronika.silinevicha@gmail.com consideration for the period 2014, 2015-2019 a period ending, on the one hand, with the adoption by the European Union of strategic decisions to combat harmful emissions into the atmosphere and the global transition to the production of electricity using renewable sources, and, on the other hand, the outbreak of the coronavirus pandemic.

The expansion of electricity production from renewable sources will grow only at the expense of wind power, since the hydro power generation capabilities of the Daugava HPP cascade are limited by its design characteristics. The results obtained in the article can serve as a basis for subsequent identification of trends in the analyzed indicators in the post-coronavirus perspective and for the development of appropriate practical recommendations.

Calculation of trends of indicators, approximating formulae dependencies and the coefficients of determination for the relevant diagrams and charts are based on big data collected from the Latvian transmission system operator Augstsprieguma tikkls, 
Central Statistical Bureau of Latvia, and Nord Pool, the Nordic power exchange. The data used in the empirical study is collected from hourly data from the period 1 January 2014 to 31 December 2019.

The analysis of a small number of selected indicators in the work is carried out using graphs and displaying on them the equations of the trends of these indicators, as well as the coefficients of determination $R^{2}$, obtained by the authors using the Trendline Excel toolkit. With a large number of analyzed indicators, their display on the graphs is cumbersome, therefore the graphs are accompanied by tables in which the trend equations and the coefficients $R^{2}$ and $R$ - the correlation coefficients between the estimated and observed values of $Y$ and $X$. Trends reflects the dynamics of growth (decrease) of statistical indicators and can be used to forecast them for a short-term period (usually for one period - a month, a year). Regression dependences, (Rawling, Pantula, Dickey, 2018) which make it possible to qualitatively assess the direction of the trend, were selected by the author from linear equations that, according to observations of $X_{i} Y_{i}$, have the following general form:

$$
Y=b X+a \text {, }
$$

where the coefficients $a$ and $b$ - are the least squares estimates.

Linear regression relationships were used only to assess the qualitative direction of trends. Other types of trends provided by the Trendline Excel toolkit are partially used in the work in order to obtain greater reliability of their direction. Recall that for a linear regression model with one parameter $X$, the coefficient $R^{2}$ is equal to the square of the correlation coefficient between the estimated and observed values of $Y$ and $X$. In estimating regression models, the value of the coefficient of determination $R^{2}$ is interpreted as the model correspondence to the presented data (Abdey, 2018).

\section{Method and materials used}

Power generation in the Baltic states is provided by condensing and co-generation TPP, HPP, and WPP. In Estonia and Lithuania, most of the electricity is generated mainly by condensing plants powered by shale oil and gas, respectively. In Latvia - at cogeneration thermal power plants and the Daugava HPP cascade, which gives significant competitive advantages in the fight against environmental pollution. According to (International Renewable Energy Agency, 2019) the total installed capacity of renewable energy facilities in 2010 and 2018, respectively: in Latvia - 1622 and $1797 \mathrm{MW}$; in Lithuania - $278 \mathrm{MW}$ and $832 \mathrm{MW}$; in Estonia - $256 \mathrm{MW}$ and $633 \mathrm{MW}$. Thus, in Latvia the production of electricity from renewable energy sources (RES) increased insignificantly during this period, while in Lithuania and Estonia this production increased by about 3 and 2.5 times. These countries were forced to significantly increase "clean" electricity production due to the consequences of the closure of the Ignalina nuclear power plant (Lithuania) and phased preparations to reduce electricity production from oil shale (Estonia).

All of the Baltic countries are experiencing power shortages. Latvia's production covers less than $90 \%$ of electricity consumption, importing it from Lithuania and Estonia, which in turn import it from other European Union countries - Finland, Sweden and Poland. Latvia also imports from third countries, such as Russia. The average daily production and consumption of electricity in Latvia depends on many factors, so Latvia imports and exports electricity by buying and selling it on the NordPool electricity exchange. Latvia imports electricity mainly at night and on weekends, when it is cheaper on the market, which allows it to reduce the flow of water in the reservoirs of the Daugava HPP cascade and use the accumulated reserves for production during peak hours. Over the past four years, electricity trade between the Baltic States and other European countries has doubled.

\section{Discussion and research results}

The dynamics of statistical natural electricity indicators in Latvia in MWh for the period 2015-2019 is presented in Table 1 and shown in Figure 1. The following designations of average hourly volumes (MWh) have been introduced: production ( $Q 1)$, consumption $Q 2)$, import $(Q 3)$, export $(Q 4)$, total exchange turnover Q5 (import + export: Q5 $=Q 2+Q 3)$ and the excess of import over export $Q 6(Q 6=Q 3-Q 4)$.

Table 1

Electricity generation, import, export and consumption in Latvia, 2014-2019

\begin{tabular}{|l|c|c|c|c|c|c|}
\hline \multicolumn{1}{|c|}{ Indicator MWh (Year) } & 2014 & 2015 & 2016 & 2017 & 2018 & 2019 \\
\hline Total net electricity production (Q1) & 4857 & 5384 & 6228 & 4401 & 6500 & 6108 \\
\hline Deliveries to the internal market, Consumption (Q2) & 7172 & 7201 & 7263 & 7278 & 7408 & 7226 \\
\hline Import (Q3) & 5338 & 5247 & 4827 & 4074 & 5172 & 4612 \\
\hline Export (Q4) & 3119 & 3424 & 3794 & 4136 & 4264 & 3494 \\
\hline Import+Export total (Q5) & 8457 & 8671 & 8621 & 8210 & 9436 & 8106 \\
\hline Import-Export (Q6) & 2219 & 1823 & 1033 & $(62)$ & 908 & 1118 \\
\hline
\end{tabular}

Source: created by the author based on Central Statistical Bureau of Latvia 


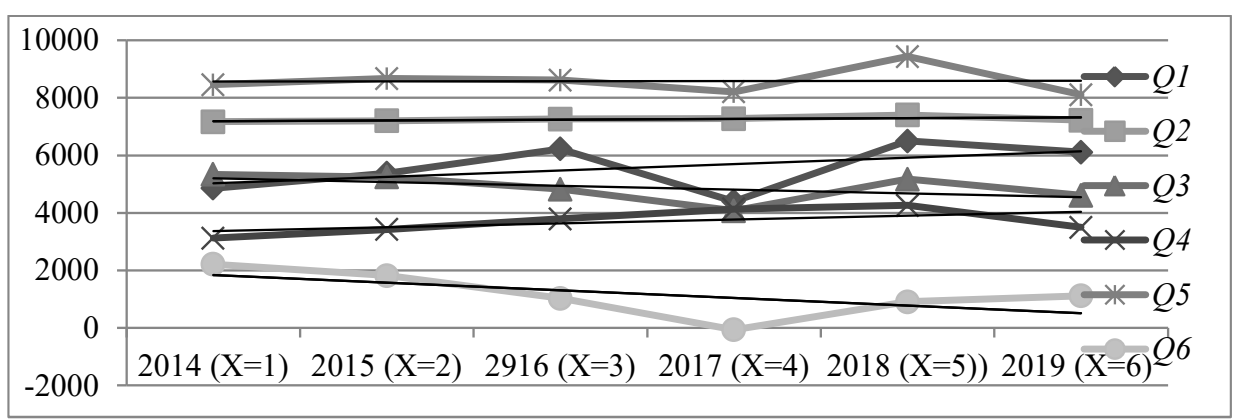

Figure 1. Dynamic of electricity generation, import, export and consumption in Latvia, 2014-2019

Source: created by the author based on data from Central Statistical Bureau of Latvia

Data on Latvia's total electricity demand, net electricity production, imports and exports for the period 2014-2019 are shown in Figure 1. There have been no significant fluctuations in final energy consumption over the last decade, moreover, the usage of electricity in 2020 decreased due to the coronavirus crisis (a state of emergency was declared in the Baltic states in mid-March to limit the spread of the COVID-19 pandemic, which affected demand for electricity, especially in the legal entity segment). Along with the increase in power generation, power exports have also largely increased (the graph shows the ratio of net power generation to power exports). The electricity import is volatile, during the researched time period, however, it is partly relating to export changes. It should be noted that Latvian exports exceeded imports in 2017. That year, Latvia's domestic electricity production covered $101 \%$ of consumption.

The data in Table 1 and Figure 1 show that electricity imports to Latvia are increasing when electricity generation at the Daugava HPP cascade decreases due to a drop in the water level in the reservoir. Accordingly, the export of electricity increases significantly with the growth of electricity generation at the Daugava HPP cascade with an increase in water inflow into the reservoir. During the observed period, only in 2017, the volume of exports $Q 4=4136$ MWh slightly exceeded the volume of imports $Q 3=4074 \mathrm{MWh}$ of electricity.

Table 2 shows the minimum, average and maximum values of the average hourly indicators $Q i$, the corresponding trend equations $Q t i$, as well as the values of the coefficients $R^{2}$ and $R$. Table 2 and Figure 1 show that annual electricity consumption in Latvia is virtually unchanged and averages $7258 \mathrm{MWh}$, peaking at $7408 \mathrm{MWh}$ in 2017 and decreasing to 7226 in 2019.

Note that the closeness of the relationship (according to Scale Chedoke) between statistical data on these indicators and linear trend equations, expressed by the coefficients $\mathrm{R} 2$, ranges from weak $(\mathrm{Q} t 1, \mathrm{Q} t 3)$ to moderate $(Q t 2, Q t 4, Q t 6)$. These equations can be used for a short-term "approximation" of the corresponding indicators for the next year, but not for an accurate estimation, since regression models with coefficients $R^{2},<1$ are of low practical value. Electricity production $(Q t 1)$, consumption $(Q t 2)$ and export $(Q t 4)$ trends are upward. The trends in imports (Qt3) and the excess of imports over exports (Qt6) of electricity are of a downward character, which indicates the dynamics of a slow but decreasing dependence of Latvia on imports of electricity. The trend of the exchange turnover of electricity $(Q t 5)$ has a neutral character with practically zero coefficient $R^{2}$, and the corresponding equation cannot be used for a short-term "approximate" forecast of this indicator.

According to (Latvenergo: Savlaicigas investīcijas modernu elektrostaciju attīstībā stiprinās Latviju, 2020) it is noted that the Baltic countries are technically capable of providing the electricity needed, but for commercial reasons it is often more profitable to import it due to high carbon dioxide emission costs

Table 2

Minimum, average and maximum values of average hourly indicators $Q i$ and their $Q t i$ trend equations

\begin{tabular}{|c|c|c|c|c|c|c|}
\hline Indicators & Qimin & Qimax & Qimid & Equation Qi & $R^{2}$ & $R$ \\
\hline Q1 & 4401 & 6500 & 5580 & Qt1 $=222.17 X+4802.1 .1$ & 0.2471 & 0.5 \\
\hline Q2 & 7172 & 7408 & 7258 & Qt2 $=25.886 X+7167.4$ & 0.339 & 0.58 \\
\hline Q3 & 4074 & 5338 & 4878 & Qt3 $=-131.66 X+5339.1$ & 0.2629 & 0.51 \\
\hline Q4 & 3119 & 4264 & 3705 & Qt4 $=0.135 .34 X+3231.5$ & 0.3294 & 0.57 \\
\hline Q5 & 8106 & 9436 & 8584 & Qt5 = 3.6857X+8570.6 & 0.0002 & 0.014 \\
\hline Q6 & $(62)$ & 2219 & 1173 & Qt6 $=-267 X+2107.7$ & 0.398 & 0.63 \\
\hline
\end{tabular}

Source: created by the author 
and lack of sufficient heat load to run large gas power plants in Riga in economic cogeneration mode.

The COVID-19 pandemic in Europe and the Baltic countries has led to an average decrease in electricity consumption of about $10 \%$ since the beginning of 2019 due to slowing economic development (Balodis, 2020). The Baltic countries have the smallest decrease in electricity consumption in the European Union: in March and April 2020, consumption decreased by $6.2 \%$ compared to the same period in 2019 (Estonia $4 \%$, Latvia $-4.3 \%$, Lithuania - 6.3\%). It is claimed that during this period of the pandemic, none of the EU countries violated or worsened the security of electricity supply, that is, they did not stop the supply of gas and electricity or reduce their production. In March 2020, the total electricity generation in the Baltic countries increased by $2 \%$, while Latvia had the highest electricity generation $-12 \%$ more than in February, and for the first time the production-toconsumption ratio was $107 \%$, while in Estonia - 48\%, and in Lithuania - 35\% (Prohorova, 2020).

Table 3 presents data on the share (\%) of electricity generated (without own consumption and losses) in Latvia from renewable sources, which are HPP and WPP, obtained by the author by calculation using statistical data from JSC "Augstsprieguma tìkls", Latvian electricity market overview. The share of electricity produced by solar energy was not taken into account. Despite the fact that in 2019 solar power plants produced 3 times more electricity than in 2018, its share (CSB 2019) in the total generated electricity is still insignificant. The total share of HPP and WPP by year is shown in Figure 2.

Figure 2 shows the dynamics of the total share of electricity produced by HPP and WPP in the total amount of electricity produced in Latvia during the period under review. The linear trend of this indicator (lower line in Figure 2), as well as the logarithmic trend, over the observed period has a neutral character with a barely noticeable increase, but with very low determination coefficients $-R^{2}=0.022$ and 0.0791 , respectively.
Table 3

Shares of electricity generated in Latvia at HPP and WPP, 2014-2019

\begin{tabular}{|l|c|c|c|c|c|c|}
\hline Indicator (\%) & 2014 & 2015 & 2016 & 2017 & 2018 & 2019 \\
\hline HPP (\%) & 34 & 30 & 50 & 58 & 37 & 34 \\
\hline WPP (\%) & 2.4 & 2.3 & 0.7 & 0.7 & 1.9 & 2.5 \\
\hline HPP+WPP (\%) & 36.4 & 32.3 & 50.7 & 58.7 & 38,9 & 36,5 \\
\hline
\end{tabular}

Source: created by the author based on JSC "Augstsprieguma tïkls". Latvian electricity market overview

From Table 3 and Figure 2 it follows: first, the share of electricity production from RES for these years averaged $42.25 \%$, with a maximum of $58.7 \%$ in 2017 and falling in 2018 and 2019; second, both the total share and its components are unpredictable, so more qualitatively this trend can be determined by the 2020 and 2021 statistics. We recall that in accordance with National Energy and Climate Plan of Latvia 2021-2030, the share of renewable energy in final energy consumption should increase (in \%) in 2020, 2022, 2025, 2027 and 2030, respectively, to 40.95, $41.25,42.543 .75$ and 45 .

Electricity, like any other product, can be bought, sold, and traded under the rules of the electricity market. This is the result of worldwide liberalization of electricity markets. In order to minimize risks, maximize profits, and make plans, it is important for electricity market participants to forecast future prices. In this paper data of Latvia's price zone in Nord Pool power market is analysed. The data set consists of historical hourly electricity prices (Eur/MWh) from January 1, 2014 to December 31, 2019.

In Figure 3 shows the dynamics of changes in the average cost (C) of one MWh of consumed electricity in Latvia (European Network of Transmission System Operators for Electricity 2020).

For the period 2014-2015, the indicators of the minimum $\left(C_{\min }\right)$, maximum $\left(C_{\max }\right)$, average $\left(C_{\mathrm{mdl}}\right)$ values are, respectively, 34.7 (2017), 50.1 (2014) and 42.35 EURO/MWh. A linear regression with a very low coefficient of determination $R^{2}=0.0116$ shows a neutral trend of this indicator with a barely noticeable downward direction. Logarithmic

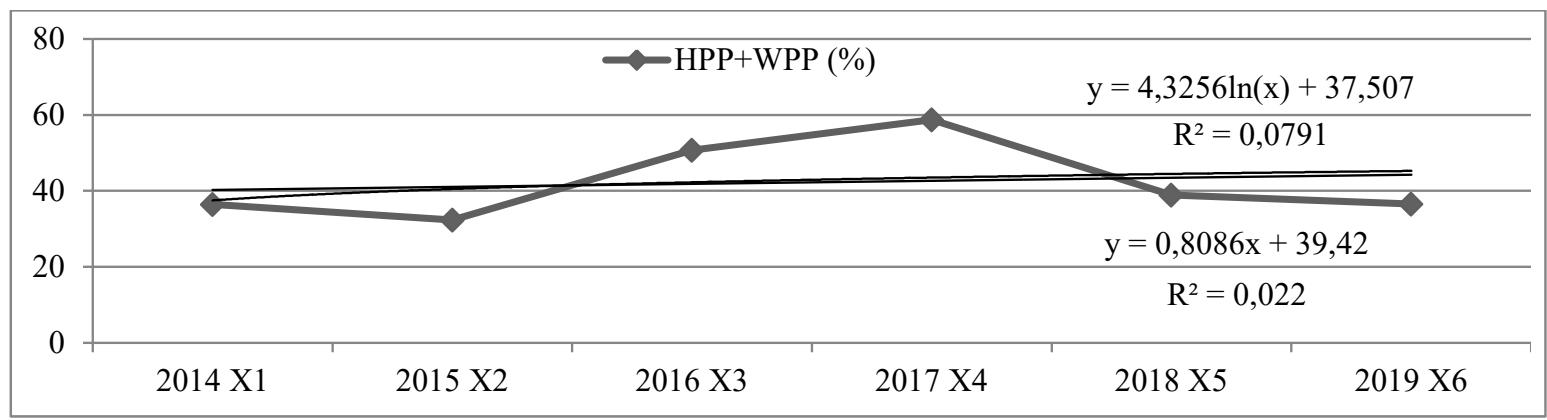

Figure 2. Dynamics of the share of HPP and WPP in the total share of electricity generated in Latvia

Source: created by the author based on JSC "Augstsprieguma tikls". Latvian electricity market overview 


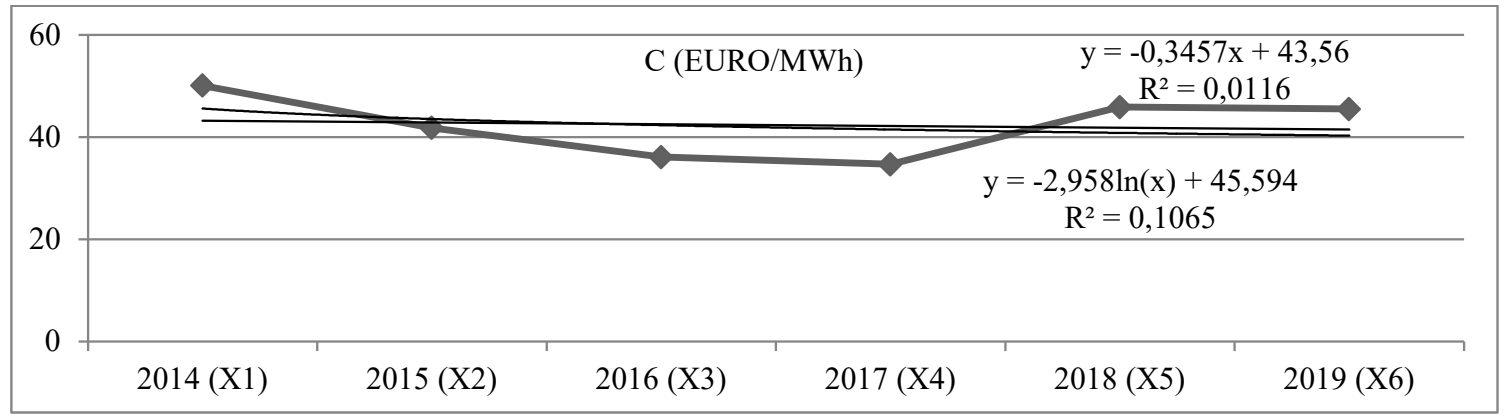

Figure 3. Dynamics of cost per MWh for Latvian electricity consumers, 2014-2019

Source: created by the author based on (European Network of Transmission System Operators for Electricity 2020)

regression with a higher coefficient $R^{2}=0.1065$ gives more confidence in the downward trend of the indicator in question. In 2018, the average electricity exchange price in the Latvian trading area was 46.28 EURO/MWh, and the average daily price ranged from 11.99 to 89.45 EURO / MWh.

The current coronavirus crisis, global hydrocarbon production processes and the hydrological situation in the Nordic countries with heavy rainfall have impacted the region's reduced demand for electricity and were a determining factor in the fall in electricity prices in the first quarter of 2020 (Prohorova, 2020).

In March, monthly electricity prices continued to decline in all Nord Pool trade zones. In the Baltic states, the average monthly price of electricity and electricity prices fell by an average of $14 \%$. The average March price in the Baltic trading zone was about 24 euro/MWh. It can be assumed that the CX trend, taking into account the 2020 results, will transform from neutral to downward.

\section{Wind power consumption characteristics and trends}

The situation with wind power capacity is different, not only in the total Baltic volumes, but also in the volumes of each country. In 2001, the installed capacity of wind power plants was only $2 \mathrm{MW}$, but in the next two years it has increased significantly to 24 MW. The next spike, when the installed capacity rose sharply to $62 \mathrm{MW}$ in total, occurred in 2012. This can be explained by the beginning of the period of operation of several wind farms, for example, 20.07 MW of installed capacity of the producer Winergy LLC. The total installed capacity of wind turbines in Latvia in 2019 was about 68 MW. In contrast, in Estonia, the installed capacity in 2019 was $310 \mathrm{MW}$, which is 4.5 times more than in Latvia. However, Lithuania is absolute leader between Baltic counties with $548 \mathrm{MW}$ installed (see Figure 4). According to the "National Energy and Climate Plan for 2021-2030", which was prepared by The Ministry of Economics of the Republic of Latvia,
Latvia plans to increase the share of RES in electricity generation by increasing the installed capacity of wind generators and solar photovoltaics, taking into account the capacity of Latvia's electricity transmission network, which currently allows to increase the amount of electricity transferred to the network by $800 \mathrm{MW}$. Taking into account the considerations of maritime spatial planning, it is planned to develop joint offshore wind farms projects (with a maximum capacity of $800 \mathrm{MW}$ ) on the Latvian-Estonian border and the LatvianLithuanian border (The Ministry of Economics of the Republic of Latvia. National Energy and Climate Change Plan, 2021-2030). The partnership process has already begun in September 2020, when Latvia's economy minister and Estonia's economy and infrastructure minister electronically signed a Memorandum of Understanding for a joint Latvian and Estonian offshore wind farm project to produce energy from renewable sources.

Other renewable energy sources are not that well developed and can be put in one group of "Other RES". This group in each country is different, it contains summarized installed capacities of different types of renewable energy sources (in Latvia $126 \mathrm{MW}$, Lithuania 199 MW, Estonia $221 \mathrm{MW}$ of total installed capacity in 2021). According to ENTSO-E, other RES in Latvia consist only of biomass, but data from "AST" JSC show biogas and some solar energy. Anyway, the volumes are gradually growing, however, in obedience to the "National Energy and Climate Plan for 2021-2030", Latvia does not plan to increase biomass and biogas capacity for electricity generation. Lithuanian other RES consists mostly of solar, biomass and other. In researched time period, the installed capacity of Lithuania's other RES fluctuated, but maintained the leading position between the Baltic states, but the situation changed in 2019, when the installed capacity of solar power in Estonia increased rapidly. Thus, Estonia's other RES are solar energy, biomass and waste.

To summarize the analysis in the Baltic countries, it should be noted that the countries use their 


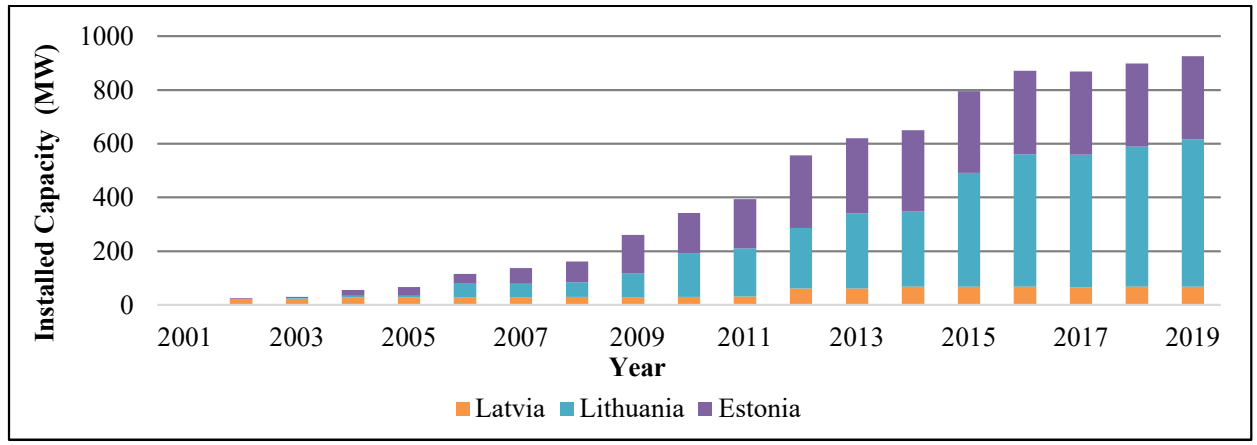

Figure 4. Total Installed Capacity of Latvia's, Lithuania's and Estonia's Wind Turbines in 2001-2019, MW

Source: created by the author, using (The Wind Power database. Production Capacities) dates

geographical, natural potential, carry out rational maintenance and work on modernization and reconstruction for a sustainable future of the energy system. Wind and solar power capacity is growing, not only in the Baltics, but all over Europe. The Baltic countries have not exploited their full potential, which, combined with the EU's 2050 carbon neutrality goal, investments, support schemes and auctions, smart strategy and implementation could lead us to a dramatic increase in renewable energy capacity, especially wind and solar.

Figures 5 and 6 show, respectively, the dynamics of statistical indicators for the planned consumption of wind energy $Q_{\text {wes }}(\mathrm{MWh})$ for the day ahead and its cost $C_{\text {wes }}(\mathrm{EURO} / \mathrm{MWh})$ on the Nord Pool exchange for Latvia (Nord Pool. Market Data, 2020). The observation covers the period from 2015 to 08/20/2020.

The trend of the Qwes indicator (Figure 5) with the coefficient $R^{2}=0.7$, also shown in Figure 5, has a clearly pronounced upward character with a high strength of connection with statistical data and indicates a steady annual increase in wind power consumption in Latvia.

The upward trend of the $C_{\text {wes }}$ indicator, shown in Figure 6 by the equation with a high value of $R^{2}=0.7$, in turn indicates a significant increase in the cost of one MWh of wind power consumed in Latvia. Over the past 5 years, this cost has doubled on average. Comparing the data for the comparable period of 2015-2019, presented in Figures 5 and 6, we get: first, the corresponding trends are multidirectional; second, the average cost of consumed wind power (123.5 EURO/MWh) is three times higher than the average cost of electricity 40.8 (EURO/MWh) consumed from all PPs. Such ratios are not yet in favor of wind power, and during its development, it is necessary to correlate economic with environmental justifications.

Let us further investigate in more detail the indicators of consumed wind energy in 2019, calculated by the authors, based on statistical data (Nord Pool. Market Data, 2020). Table 4 shows the author's calculations of the amount of wind power planned for consumption a day ahead and its cost on the Nord Pool exchange in the relevant month (MWh, EURO/MWh):

- $\hat{W}, \hat{C}$ - hourly average;

- $\hat{W}_{p}, \hat{C}_{W p}$ - average values during peak hours from 8.00 to 12.00 .

Graphs displaying the dynamics of monthly changes in $\hat{W}, \hat{W}_{p}(\mathrm{MWh})$, and $\hat{C}, \hat{C}_{W p}(\mathrm{EURO} / \mathrm{MWh})$ are shown in Figure 7 and 8.

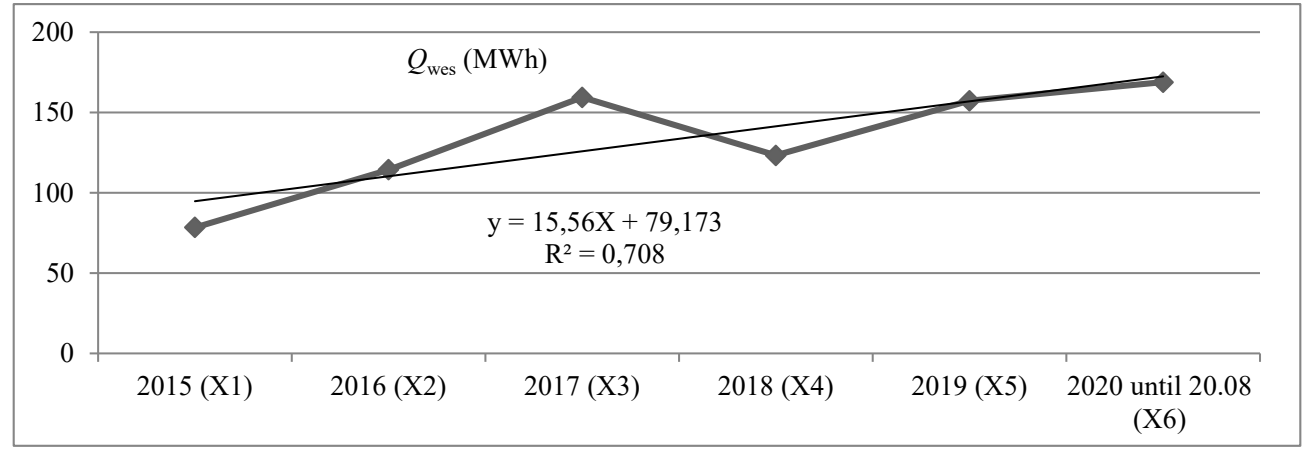

Figure 5. Dynamics of planned wind power consumption for the day ahead in Latvia, 2015-2020

Source: created by the author based on (Nord Pool. Market Data 2020) 


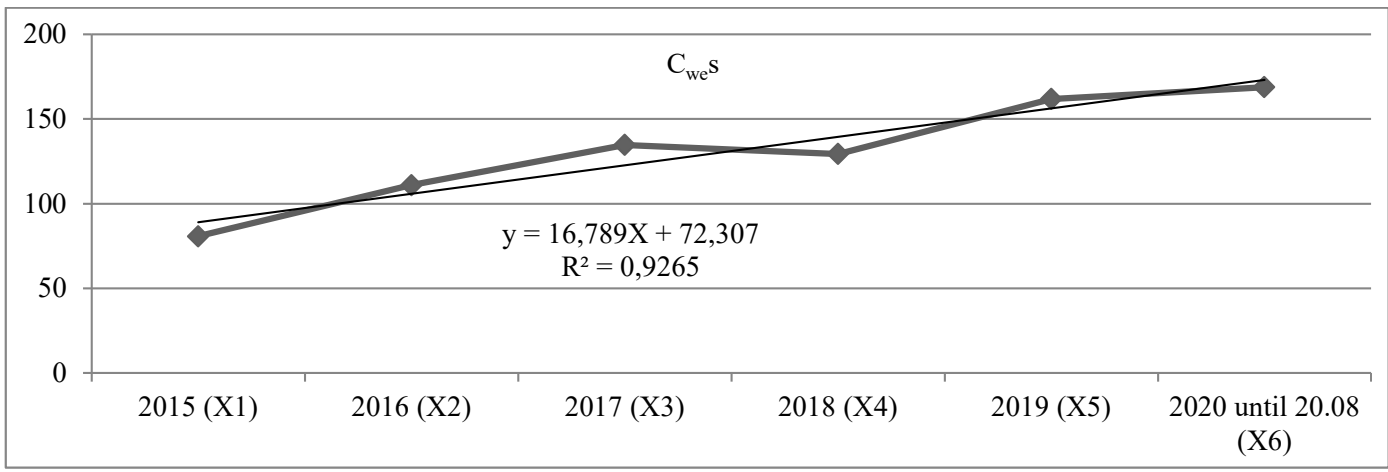

Figure 6. Dynamics of the cost on the Nord Pool exchange of wind energy planned for consumption a day ahead in Latvia, 2015-2020

Source: created by the author based on (Nord Pool. Market Data 2020)

Table 4

Estimated indicators of wind power consumption in Latvia, 2019

\begin{tabular}{|l|c|c|c|c|}
\hline \multicolumn{1}{|c|}{ Month } & $\hat{W}$ & $\hat{C}$ & $\hat{W}_{p}$ & $\hat{C}_{W p}$ \\
\hline January & 171 & 57 & 174 & 64 \\
\hline February & 219 & 47 & 211 & 50 \\
\hline March & 222 & 40 & 230 & 43 \\
\hline April & 141 & 44 & 118 & 52 \\
\hline May & 135 & 44 & 123 & 57 \\
\hline June & 89 & 45 & 76 & 66 \\
\hline July & 122 & 49 & 96 & 61 \\
\hline August & 58 & 39 & 47 & 60 \\
\hline September & 161 & 49 & 149 & 67 \\
\hline October & 159 & 47 & 153 & 56 \\
\hline November & 183 & 45 & 181 & 48 \\
\hline December & 224 & 39 & 213 & 42 \\
\hline
\end{tabular}

Source: created by the author based on (Nord Pool. Market Data 2020)

The graphs of the $\hat{W}$ and $\hat{W}_{p}$ indicators (Figure 7 ) practically repeat each other, with close monthly values and close averaged values of 157 and $148(\mathrm{MWh})$, which indicates that the peak periods practically do not affect the change in the trend of consumed wind energy. At the same time, the months of the year significantly affect the trend of these indicators, which take the lowest values in the warm months from April to September and the highest in the rest of the months.

The graphs of the $\hat{C}$ and $\hat{C}_{W p}$ indicators (Figure 8) are also similar in character. In general, the indicator values during peak hours $\left(\hat{C}_{W_{p}}\right)$ are higher than the average hourly monthly values. Their averaged values 45 and 55 (EURO/MWh) differ by only $18 \%$.

\section{Conclusions}

1. Latvia's electricity production, consumption and export trends are weak but upward. Electricity import and excess import over export trends are downward, indicating the dynamics of Latvia's slow but decreasing dependence on electricity imports. Cannot be used for a short-term " approximate" forecast of this indicator.

2. The trend of planned wind power consumption for the day ahead in Latvia has a clearly pronounced upward character with a high strength of connection with statistical data (coefficient $R^{2}=0.7$ ) and indicates a steady annual increase in wind power consumption

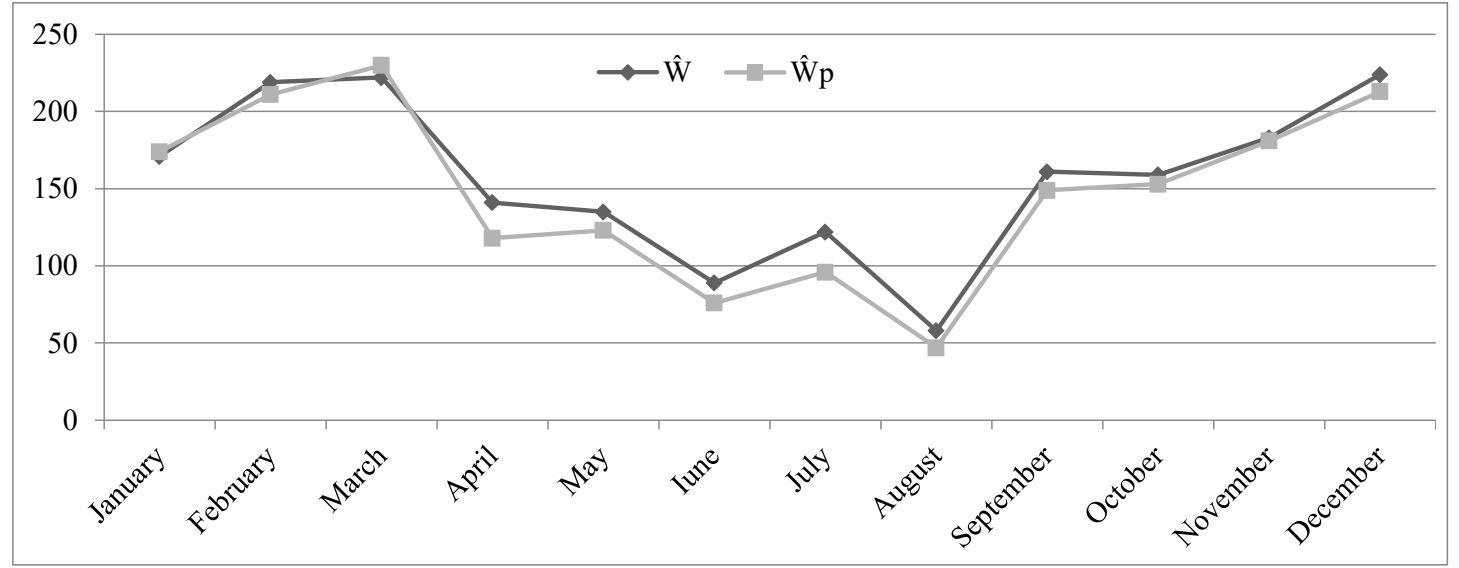

Figure 7. Dynamics of average hourly values of indicators $\hat{W}$ and $\hat{W}_{p}(\mathbf{M W h}), 2019$

Source: created by the author based on (Nord Pool. Market Data 2020) 


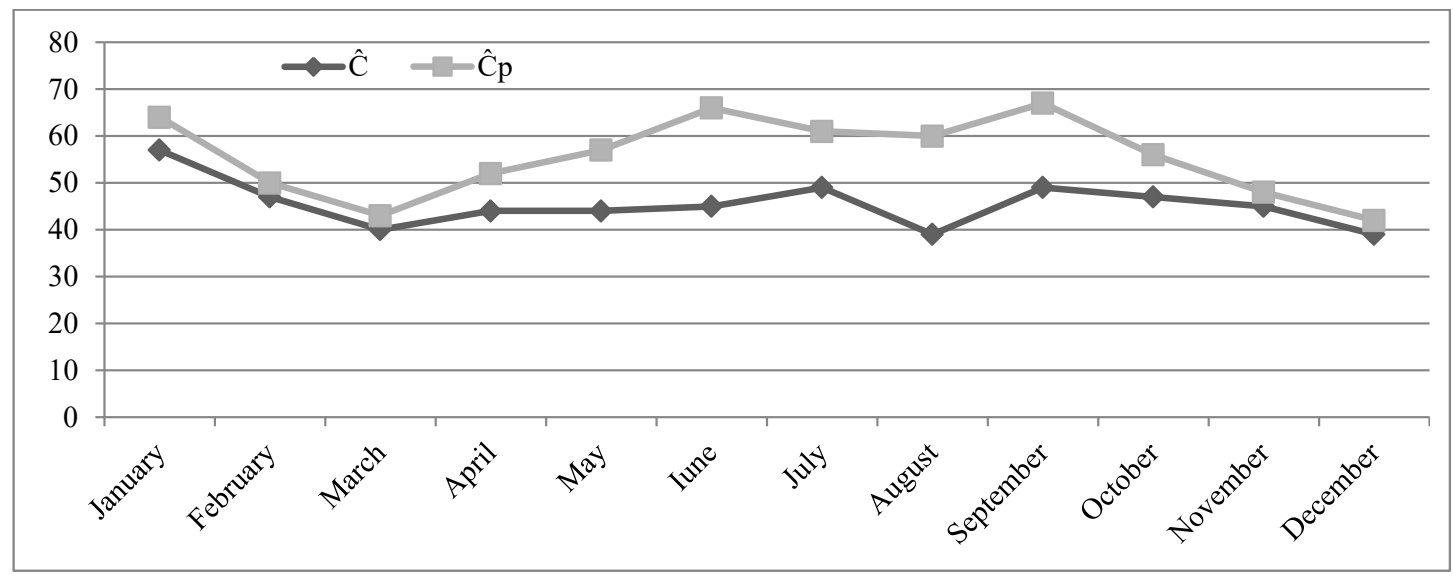

Figure 8.Dynamics of average hourly values of indicators $\hat{C}$ and $\hat{C}_{W_{p}}, 2019$

Source: created by the author based on (Nord Pool. Market Data 2020)

in Latvia, which corresponds to the goals of increasing the share of RES in final energy consumption should grow and reach its share up to $45 \%$ by 2030 . At the same time, the upward trend in the cost of one MWh (wind power consumed in Latvia with a high value of $R^{2}=0.7$ ) does not correlate with the trend in its consumption. This circumstance, as well as the consequences of the coronavirus pandemic, may require an adjustment of plans to increase electricity consumption from RES, which will require a more detailed assessment of the volume of wind energy imports and possibly implementation of measures to increase wind energy production capacity in Latvia.

\section{References:}

Abdey, J. (2018). Data Analysis for Management Programme, Module 6 Unit 1, London School of Economics and Political Science, UK, pp. 8-16.

Balodis, M. (2020). Krīzes ietekme uz energéêtikas nozari Eiropā un Baltijā. Elektroenergijas tirgus apskats Izdevums Nr. 104/2020. gada Aprīlis. Available at: https://latvenergo.lv/storage/app/media/uploaded-files/ ETA_apr_2020.pdf

Central Statistical Bureau of Latvia. Available at: www.csb.gov.lv

European Network of Transmission System Operators for Electricity. Available at: https://www.entsoe.eu International Renewable Energy Agency (IRENA). Available at: https://irena.org/publications/2019/Jul/ Renewable-energy-statistics-2019

JSC "Augstsprieguma tìkls". Latvian electricity market overview. Available at: http://www.ast.lv/en/electricitymarket-review?year $=2017 \&$ month $=10$

Prokhorova, R. (2020). AS Covid-19 izraisa pieprasijuma samazinājumu. Elektroenergijas tirgus apskats Izdevums Nr. 104/ 2020. gada Aprīlis. Available at: https://latvenergo.lv/storage/app/media/uploaded-files/ ETA_apr_2020.pdf

Rawlings, J. O., Pantula, S. G., \& Dickey, D. A. (2018). Applied Regression Analysis. A research tool. $2 \mathrm{end}$ ed. Springer-Verlag NY, p. 7, 21, 87, 107-110. ISBN 0-387-98454-2

The Ministry of Economics of the Republic of Latvia. National Energy and Climate Change Plan 2021-2030. Available at: https://www.em.gov.lv/lv/nozares_politika/nacionalais_energetikas_un_klimata_plans/

The Wind Power database. Production Capacities. Available at: https://www.thewindpower.net/country_en_42_ latvia.php

Nord Pool. Market Data. Available at: https://www.nordpoolgroup.com/

Legal acts of the Republic of Latvia. Electricity Market Law. Available at: https://likumi.lv/ta/en/en/id/ 108834-electricity-market-law

Viskuba, K., \& Silinevicha, V. (2020). Wind Farm Project Results and Innovative Business Models. Humanities and Social Sciences: Latvia, vol. 28, issue 1, pp. 5-29. ISSN 1022-4483

Viskuba, K., \& Silinevicha, V. (2021). Renewable Energy Sources in the Baltic States and New Business Approach of the Sector. Vilnius University Open Series, pp. 120-127. DOI: https://doi.org/10.15388/VGISC.2021.16 